\title{
An Empirical Study on the Customer Loyalty to Sports Goods Brand
}

\author{
Zhang Yu ${ }^{1,2}$, Li Pengsong ${ }^{1}$, Cao Houwen ${ }^{1}$, Cao Ling ${ }^{1}, \mathrm{Li} \mathrm{Na}^{3,}$ * \\ ${ }^{1}$ Department of Physical Education, Dalian University of Technology, Dalian, China \\ ${ }^{2}$ State Key Laboratory of Fine Chemicals, Dalian R\&D Center for Stem Cell and Tissue Engineering, Dalian University of Technology, Dalian, \\ China \\ ${ }^{3}$ Dalian Medical University, Dalian, China
}

\section{Email address:}

55286747@qq.com (Li Na)

*Corresponding author

\section{To cite this article:}

Zhang Yu, Li Pengsong, Cao Houwen, Cao Ling, Li Na. An Empirical Study on the Customer Loyalty to Sports Goods Brand. Science Journal of Education. Vol. 5, No. 3, 2017, pp. 111-114. doi: 10.11648/j.sjedu.20170503.16

Received: December 26, 2016; Accepted: April 18, 2017; Published: April 21, 2017

\begin{abstract}
The research objective is to explore the formation mechanism of the customer loyalty to sports goods brand and improve the competitiveness of sports goods enterprises. Based on the review of relevant literatures, this paper mainly applied regression analysis method in empirical research. It concluded that the perceived quality is positively correlated with customer value and customer value is positively correlated with customer satisfaction, while customer's satisfaction is positively correlated with customer loyalty.
\end{abstract}

Keywords: Sports Goods Brand, Customer Loyalty, Empirical Study

\section{Introduction}

After more than 20 years of development, Lining and other well-known national brands have emerged in China's sporting goods market. But in the fierce market competition, compared with foreign brands such as Nike and Adidas, the brand competitiveness is relatively low [1]. Usually most of the sales of enterprises come from a small part of loyal customers [2]; hence the improvement of customer loyalty is an effective way to win in the competition [3]. Generally, studies have mainly focus on the role of customer loyalty to sports goods brand, but few empirical studies on the formation mechanism of customer loyalty $[4,5]$. Thus how to improve customer loyalty is still blind for many sports goods enterprises. Under this background, this paper discussed the formation mechanism of customer loyalty to sports goods brand by the method of empirical research.

\section{Research Objects and Methods}

\subsection{Research Objects}

The object of study is the customer of sports goods brand, concretely the college students from 12 universities in Liaoning province.

\subsection{Research Method}

First of all, the definition of each concept and their measurement methods principally referred to the domestic and foreign literatures. The definition of perceived quality is to consider all aspects, thereby making evaluation for the overall quality [6]. The test items was "considering all aspects of the sports brand, your assessment of the overall quality is from 'very poor' to 'very good' evaluation"; Customer value is defined as the evaluation of the overall value of the product relatively to the price and utility [7]. Its test item was "for all aspects of the sporting goods brand, according to the price, the evaluation level was from 'worthless' to "value for money"'; Customer satisfaction [8]is defined as general satisfaction. The test item was "giving 
overall evaluation for the product from the 'very far from the expectations' to 'fully meeting the expectations' based on considering all aspects of the product; the concept of customer loyalty is defined as repeat purchase intention [9], whose test items was "the possibility for buy this sports brand once again from 'impossible' to 'completely possible" $[1,10]$. The above measurements are based on the 7 levels, scoring from 1 to 7 .

This research adopted the method of random sampling. 280 copies of questionnaires were issued to undergraduates from 12 colleges in Liaoning Province from March $1^{\text {st }}$ to March $12^{\text {th }}$ in 2010. 243 copies of questionnaires were recovered, and finally 206 copies of questionnaires was valid after excluding incomplete 37 copies of questionnaires, satisfying the criteria that effective sample recovery rate needs to reach $70 \%$, at the same time the effective sample numbers are at least 5 times of the measurement items. Among them, male students accounted for $70.8 \%$, and female students accounted for $29.2 \%$. Descriptive statistical analysis and regression analysis were adopted for data process using SPSS 16.0 statistical software. When $\mathrm{P}<0.05$, there were significant differences.

\section{Results and Analysis}

\subsection{Descriptive Statistical Results and Analysis [Table 1]}

Table 1. The statistical results of sports goods brand of customer loyalty.

\begin{tabular}{lllllll}
\hline Brands & Nike & Adidas & Lining & Anta & Kuangwei & Others \\
\hline Frequency & 72 & 30 & 28 & 21 & 14 & 32 \\
Percent & $35 \%$ & $14.6 \%$ & $13.6 \%$ & $10.2 \%$ & $6.8 \%$ & $19.8 \%$ \\
\hline
\end{tabular}

As can be seen from the table 1, the proportion of customers loyal to Nike ranked first, reaching 35\%. Adidas ranked second, the proportion reached $14.6 \%$. Both of them reached nearly $50 \%$, which showed that the customers who are loyal to the two foreign brands accounted for nearly half of the total sample. Lining ranked third, the proportion of $13.6 \%$, close to Adidas, which explained that the market acceptance for some Chinese brand have not much difference with international first-class brands. The research objects were loyal to 19 sports goods brand, for those brands whose rank was after the fifth place, the total proportion of loyal customers was $19.8 \%$, and all below $5 \%$, indicating that these brands lack competitiveness [Table 2].
Table 2. Descriptive statistical results and analysis of variables.

\begin{tabular}{lllll}
\hline & $\begin{array}{l}\text { Perceived } \\
\text { quality }\end{array}$ & $\begin{array}{l}\text { Customer } \\
\text { value }\end{array}$ & $\begin{array}{l}\text { Customer } \\
\text { satisfaction }\end{array}$ & $\begin{array}{l}\text { Customer } \\
\text { loyalty }\end{array}$ \\
\hline Average & 5.74 & 5.09 & 5.55 & 5.65 \\
variance & 1.19 & 1.30 & 1.03 & 1.21 \\
\hline
\end{tabular}

The mean value of the above four variables was greater than 5, which indicated that the customer had a higher evaluation of the above variables. The average value of perceived quality was 5.74 , and the standard deviation was 1.19 , which showed that the quality of sporting goods was very high with less volatility. The average value of customer value was 5.09, and the standard deviation was 1.30 , which illustrated that the customer value of the sports goods brand was relatively low, and the fluctuation was relatively large. The average value of customer satisfaction was 5.55, and the standard deviation was 1.03 , which indicated that the level of customer satisfaction was medium, and the fluctuation was very small. The average customer loyalty was 5.65 , and the standard deviation was 1.21 , which showed that the brand loyalty of sports goods was relative high with big fluctuation.

\subsection{Regression Results and Analysis [Table 3]}

In the impact path of perceived quality on customer value, the adjusted $\mathrm{R}^{2}$ was equal to $16 \%$, which indicated that $16 \%$ of customer value changes were caused by perceived quality. The standardized path coefficient was 0.41 , which showed that when the perceived quality was improved by $1 \%$, the customer value increased by $0.41 \%$. The $\mathrm{F}$ was equal to 41.16 greater than 20 , and $\mathrm{T}$ was equal to 6.42 greater than 1.96 , proving that the relationship between perceived quality and customer value have underwent test. Therefore, perceived quality and customer value were positively correlated. Perceived quality was the overall evaluation of product quality, the higher the evaluation indicated that the better the quality of the product, the better to meet customer needs. Customer perceived value was equal to the income minus the perceived loss. When buying sports goods, customers always desired the price cost to the minimum, and get more benefits from it in order to maximize meeting their own needs. Therefore, in the purchase of sports goods, customers often carry out comparative analysis from the two aspects of earnings and cost, and then choose the brand with highest income and lowest cost. When perceived quality is higher, the customers' income turns greater, in the case of constant cost, the greater the value of the customers.

Table 3. Regression Results and Analysis.

\begin{tabular}{|c|c|c|c|c|c|}
\hline Path & The adjusted $R^{2}$ & standardized path coefficient & F value & T value & Conclusion \\
\hline Perceived quality $\rightarrow$ Customer value & 0.16 & 0.41 & 41.16 & 6.42 & Support \\
\hline Customer value $\rightarrow$ Customer satisfaction & 0.21 & 0.46 & 54.38 & 7.37 & Support \\
\hline Customer satisfaction $\rightarrow$ Customer loyalty & 0.19 & 0.44 & 43.84 & 6.92 & Support \\
\hline
\end{tabular}

Note: the $\mathrm{P}$ value was less than 0.5 .

In the impact path of customer value on customer satisfaction, the adjusted $\mathrm{R}^{2}$ was equal to $21 \%$, which showed that $21 \%$ of customer value changes were caused by perceived quality. The standardized path coefficient was 0.46 , indicating that when perceived quality was improved by $1 \%$, the customer value increased by $0.46 \%$. F was equal to 54.38 greater than 20 , and $\mathrm{T}$ was equal to 7.37 greater than 1.96 , also the relationship between perceived quality and customer 
value have been through the test. Therefore, perceived quality and customer value were positively correlated. If the product meet the demand of customer, and then customer satisfaction will be created. If the perceived value achieve even beyond the pre-purchase expectations, then the customer will be greatly satisfied; conversely, the customer will be disappointed.

In the influence of customer satisfaction on customer loyalty, the adjusted $\mathrm{R}^{2}$ was equal to $19 \%$, which showed that $19 \%$ of the changes in customer loyalty were caused by the perception of satisfaction. The standardized path coefficient was 0.44 , which showed that when the customer satisfaction was increased by $1 \%$, followed by the customer loyalty increasing by $0.44 \%$. F was equal to 43.84 greater than 20 , and $\mathrm{T}$ was equal to 6.92 greater than 1.96 , illustrating the relationship between customer satisfaction and customer loyalty have been through the test. Therefore, perceived satisfaction was positively related to customer loyalty. Customer satisfaction can contribute to the formation and maintenance of customer loyalty, which was the main driving factor of customer loyalty. High satisfaction and pleasure create a kind of emotional resonance with the brand, accordingly which creates a high degree of customer loyalty. For the times to buy the same brand, the customers with a high degree of satisfaction will be more than the low-satisfaction customers. When customer is satisfied with one sport goods brand, he is more willing to buy again, that is, the level of customer satisfaction has a strong influence on customer repeat purchase.

It can be seen from table 3 , the perception quality have low explanation on the change of customer value, only $16 \%$. The standardized path coefficient was also the minimum, only 0.41; Customer value has the largest influence on the change of satisfaction of customers, reaching $21 \%$, and the standard path coefficient was 0.46 , also the maximum. Customer satisfaction has an important impact on customer loyalty, whose degree of interpretation was $19 \%$, and its standardized path coefficient was 0.44 .

\section{Conclusions and Suggestion}

\subsection{Conclusion}

Foreign brands occupy the dominant position of China's sporting goods market. Nearly half of the customers were loyal to Nike and Adidas. And the price of the two sports goods brand was the highest in similar products, stating that the ability to buy high-end brand of college students was strong. There was a higher proportion of high-end brand loyalty. The ration of customer loyalty to Lining was close to Adidas. Some sports brands in domestic can compete with foreign brands. The customer loyalty was formed through the accumulation of perceived quality, customer value, and customer satisfaction. Perceived quality was positively correlated with customer value, but the correlation coefficient was small, which showed that the quality of perception had positive effect on customer value, and other factors also play an important role in customer value. Customer value and customer satisfaction were positively correlated, and the correlation coefficient was large, which illustrated that the customer value had an important effect on customer satisfaction. Customer satisfaction and customer loyalty were positively correlated, and the correlation coefficient was also large, which explained that customer satisfaction had an important effect on customer loyalty.

High technology and high quality supports the brand development. For example, Nike and Adidas, the brand is "JUST DO IT". That is their constant innovation. At present, China's sporting goods mostly rely on processing and imitation. Technological content of products is low. As a result, enterprises produced low-grade products, failed to investigate and analyze the market demand, and finally, without designing the world's leading brands of products. It is said that the domestic low-end market is potential for development. However, if there is no obvious difference in the characteristics of the product, with foreign sports goods at the same price level has no comparative advantage, in the face of famous brand challenges, our brand will be difficult.

China's sporting goods enterprise products is single, lack of core products, enterprises cannot accurately to the brand positioning, will not be able to let people have a deeper understanding of the brand duplication. Market for some products need to be developed and undeveloped or there is a great development space, but failed to grasp the enterprise. Nike and Adidas in the early stages of its brand recognition has a clear market positioning. In the fierce competition with other brands, in the premise of ensuring that the original brand is not the core of the premise of constant innovation of products. Nike's main product is a series of basketball; Adidas is a football series; Adidas and Nike scale expansion and efficiency improvement are carried out in this way. While the domestic sports brand is simply the pursuit of fashion creation, sports atmosphere is not strong, the lack of core products. For example, "XTEP", "Conway", although also made some market benefits, but not the core products, more like leisure products, sports goods is far from the height of the spleen.

\subsection{Suggestion}

The empirical test shows that the product quality has a direct positive effect on customer satisfaction influence of brand image on customer satisfaction. Sporting goods enterprises to improve the quality of products, to stay under the impression of high quality, the formation of high visibility, access to a good reputation from improve customer satisfaction. As mentioned above, the product quality, brand image and customer satisfaction have a direct positive impact, the close relationship between product quality and brand image is not ignored, so the quality of products for the customer satisfaction. Indirect effects can be expressed through the brand image. The high-end sports goods should be developed. With the relevant conditions, China's sporting goods companies should be positioned in the high-end market through developing high quality sports goods, 
providing high quality service and setting up the high-end brand image, and appropriately improve the product price. The customer loyalty was improved by enhancing perceived quality, customer value, and customer satisfaction. China's sports goods enterprises should consider the needs of customers, strengthen the sports quality, and provide more value for customers so that improving customer loyalty, and then customers will be satisfied with the products and services to purchase repetitively.

Brand culture, refers to the identification of a consumer product or service name, and make similar products and services to distinguish nouns, mark, symbol or design, or a combination of these elements; refers to all cultural phenomena and cultural characteristics in the brand and brand deposition in the business activities, and they represent the sum the interests of the cognitive and emotional attributes, cultural traditions and values of the personality image. [9] brand culture connotation is the core resource of brand value, the consumer's preference for the brand is not based on the brand's attributes, but on the cultural connotation of the brand. Therefore, sporting goods enterprises should pay attention to build brand culture, enrich the cultural connotation of the brand, enhance the brand's market competitiveness. Philip Knight", sports performance, free and easy, free movement of spirit" as the Nike brand culture, make known to every family in the global scope. China is a civilized country with a long history of 5000 years. We can combine the image and function of the brand with the national culture. At the same time, we should learn from foreign mature brand culture concept and operational experience, and strive to enhance the brand value, and strive to create a strong national brand. [10] seize the opportunity, development and the competitiveness of the brand development of sports goods enterprises to enhance cooperation, and not rely on an independent development, but need to strengthen the cooperation and exchange, in order to seek greater development space. Sporting goods enterprises in China should use the preferential terms of WTO for developing countries, cooperate with the government, cooperate with the media, strengthen the propaganda and reporting of the brand, and create an international image. China's sports goods enterprises through various sports sponsored charitable activities and major sports events of this platform to strengthen its brand publicity and reports, to create a good brand image and social reputation, especially should pay attention to shaping the international image, and strive to make our country sports brand in the international market have higher visibility and strive to enter the international market.

\section{Acknowledgments}

This work was supported by National Science Foundation of China (DUT16rw001) and Liaoning Province Education Science "12th Five-Year" planning college students ideological and political education special (JGZXS13039).

\section{References}

[1] Anggraeni, A. and Rachmanita, Effects of Brand Love, Personality and Image on Word of Mouth; the Case of Local Fashion Brands Among Young Consumers. Procedia - Social and Behavioral Sciences, 2015. 211: p. 442-447.

[2] Cai, Y., G. Zhao, and J. He, Influences of two modes of intergenerational communication on brand equity. Journal of Business Research, 2015. 68(3): p. 553-560.

[3] Brashear-Alejandro, T., J. Kang, and M.D. Groza, Leveraging loyalty programs to build customer-company identification. Journal of Business Research, 2016. 69(3): p. 1190-1198.

[4] Chang, S. and H.J. Gibson, The relationships between four concepts (involvement, commitment, loyalty, and habit) and consistency in behavior across leisure and tourism. Tourism Management Perspectives, 2015. 13: p. 41-50.

[5] Goyal, P. and U. Chanda, A Bayesian Network Model on the association between CSR, perceived service quality and customer loyalty in Indian Banking Industry. Sustainable Production and Consumption.

[6] Dumortier, J., et al., Effects of providing total cost of ownership information on consumers' intent to purchase a hybrid or plug-in electric vehicle. Transportation Research Part A: Policy and Practice, 2015. 72: p. 71-86.

[7] Fetscherin, M. and D. Heinrich, Consumer brand relationships research: A bibliometric citation meta-analysis. Journal of Business Research, 2015. 68(2): p. 380-390.

[8] Gallarza, M.G., et al., Value dimensions in consumers' experience: Combining the intra- and inter-variable approaches in the hospitality sector. International Journal of Hospitality Management, 2015. 47: p. 140-150.

[9] Khan, I. and Z. Rahman, A review and future directions of brand experience research. International Strategic Management Review, 2015.3(1-2): p. 1-14.

[10] Marakanon, L. and V. Panjakajornsak, Perceived quality, perceived risk and customer trust affecting customer loyalty of environmentally friendly electronics products. Kasetsart Journal of Social Sciences. 